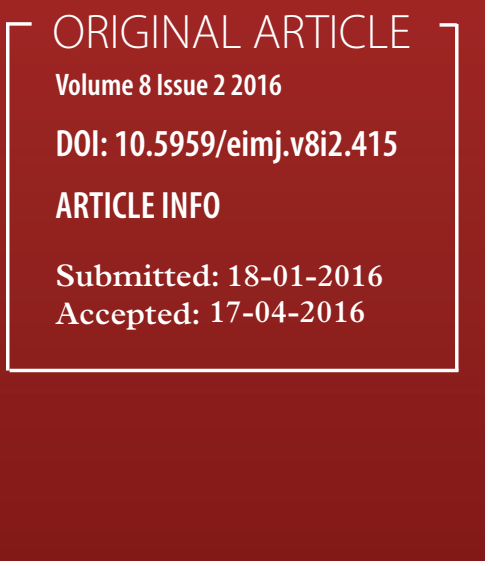

\title{
Medical Students' Preparedness as Junior Doctors on Palliative Care Issues: A Single Centre Study
}

\author{
Muhamad Riduan Daud', Lee Chee Chan², Fahisham Taib \\ ${ }^{1}$ School of Medical Sciences, Universiti Sains Malaysia, Kelantan \\ ${ }^{2}$ Paediatric Palliative Care Specialist, Hospital Kuala Lumpur
}

To cite this article: Muhamad Riduan Daud, Lee Chee Chan, Fahisham Taib. Medical students' preparedness as junior doctors on palliative care issues: a single centre study. Education in Medicine Journal. 2016;8(2):3-14. DOI: 10.5959/eimj.v8i2.415

To link to this article: http://dx.doi.org/10.5959/eimj.v8i2.415

\begin{abstract}
Introduction: Palliative care teaching has little emphasis during the undergraduate period. Most teachings in medical school are geared towards preventive and curative approach. Competency in palliative care including therapeutic and effective communication has been the taught indirectly without emphasis on other areas. We investigate medical students' preparedness on palliative care subjects using past studies questionnaire to evaluate knowledge, attitudes and understanding on end of life issues. Method: Cross sectional study was performed on the final year medical students (class 2015) from a public university in the northern state of Peninsular Malaysia. Proforma was adopted from the previously published studies covering the aspect of knowledge, attitude, end-of-life, advanced directive and bioethical principles in palliative care. Conceptual framework of final year medical students' preparedness was ascertained following impartment of palliative care knowledge, either directly or indirectly, after the exposure and completion of the clinical attachment. Results: The study elicited a $78.5 \%$ response rate where 133 students replied out of 177 total students. Overall the knowledge and attitude of palliative care were good. There were some misconceptions especially the use of morphine and role of physician in the management of dying patients. Conclusion: There were gaps identified following the completion of the study. Misunderstanding in different aspect of care should be remedied with more exposure and practicality suitable to undergraduate medical curriculum learning.
\end{abstract}

Keywords: Medical students, Palliative, Knowledge, Attitude, Preparedness

CORRESPONDING AUTHOR Muhamad Riduan Daud, School of Medical Sciences, Universiti Sains Malaysia, 16150 Kubang Kerian, Kelantan | Email: eewey_2104@yahoo.com

\section{Introduction}

Palliative care is a specialised medical scope that focuses on improving the quality of life for patients with life limiting conditions. This is achieved by a multi-dimensional and meticulous clinical assessment directing at symptoms control to achieve satisfactory outcome. Despite the evolving improvement of palliative care understanding in health care training and undergraduate education, preparedness of undergraduate students prior to housemanship has been inadequately examined and addressed. Health care professionals are much comfortable treating curative medical conditions, but have uneasiness when dealing with dying patients (1). From the literature, it was found that medical practitioners have inadequate knowledge, 
training and clinical experiences in palliative care (2). Medical graduates should be equipped and ready due to the likeliness to encounter end of life cases during their medical career.

Development of palliative care in Malaysia started on voluntary basis until the Malaysian Ministry of Health established palliative care units in the hospital settings following the development of the National Health Policy. As palliative care service expanded, there is little emphasis of teaching in the undergraduate medical curricula. Battersby commented that there was almost non-existence of palliative care module or teaching in undergraduate medical curriculum in some institutions (3). At the Universiti Sains Malaysia, the students' exposure to palliative care cases is very limited. This includes one or two lectures during the interdisciplinary activities (IDA), personal clinical encounter and brief clinical attachment to community palliative care team. Medical curriculum has undergone rapid changes and no longer emphasis on the understanding and curing the diseases only, but must also cover on the social and community aspects in a holistic way. This is particularly important in the palliative care setting.

The objective of the study is to assess the final year USM medical students' knowledge and their preparedness towards palliative care during the intern year, with the view to develop an integrated module in the future medical undergraduate curriculum.

\section{Methodology}

\section{Participants}

The study was conducted during the starting of final year posting for the session 2015/2016. All fifth year students were enrolled into the study. The list of participants was obtained from Academic Office whereby the participants were divided into seven clinical groups of clinical rotation throughout the academic session. During the year four, most of the participants have undergone various postings and have some exposure on palliative care either indirectly through clinical attachment in the hospital or directly during the "Problem Based Learning" or interdepartmental activities. Some students were involved in caring after patients with chronic diseases during the Community and Family Case Study (CFCS). This practicum allowed exposure to various aspect of palliative care management with altruistic and humanistic values.

\section{Study Design and Setting}

This was a descriptive cross sectional study conducted in a single centre using a selfadministered and previously validated questionnaire from previous studies to the fifth year undergraduate medical students at the School of Medical Sciences, Universiti Sains Malaysia. The students have spent most of their time at Hospital Universiti Sains Malaysia, a tertiary and referral centre which can accommodate about 950 beds for East Coast of Malaysia. During the clinical rotation, the students have been exposed to various chronic diseases with complex palliative care issues, either in adult or paediatric cases.

\section{Study Tools}

Various sets of questionnaire covering knowledge and attitude towards palliative care $(1,4,13)$, end of life $(5,8)$, advanced directive (6) and bioethical concept in palliative care (7) were utilised. These questionnaires were reviewed in the initial stage and minimal changes were made to accommodate local relevancy, before distribution to the participants.

The questionnaires consisted of four domains. The first part is related to sociodemographic data and generally enquiry about exposure to the palliative and care for dying. The second part is related to assessment on knowledge and attitude towards palliative care. A series of 30 
questions are used to test students' actual knowledge on palliative care. The question response is marked on a 5-point Likert scale. In the subsequent domain, the questions are focused about the end of life issues and the preparedness level among the respondents to teach and provide care at the end of patients' life. The third domain questioning respondents regarding advanced directive which consisted of eight questions related to the general knowledge and view on the subject. For the final domain, it assessed the opinion towards barrier in palliative care learning and practice.

\section{Procedure and Statistics}

Distribution of proforma was done via the group leaders of each group entering paediatric posting. There were seven groups of final year students consisted of 25-27 students each. The students were instructed to answer based on their understanding anonymously and participation was on voluntary basis; the students may choose to opt out of the study if they are not interested to participate. The questionnaire was returned back after a week by the appointed group leader. Descriptive data obtained, organised and analysed using statistical software, SPSS version 22.0.

\section{Results}

A total of 177 questionnaires were distributed to all fifth year medical students. The completed and returned questionnaires was 133; this gave a response rate of $78.5 \%$. There were $33.8 \%$ of male and $66.2 \%$ of female medical students involved. The respondents comprised of $55.4 \%$ Malays and $44.6 \%$ were from other races. The Muslims accounted for $57.5 \%$ and the balanced of $42.5 \%$ were from other religious denominators. There were $49.6 \%$ of the students who have had exposure to palliative care teaching, $56.8 \%$ had had experience with the death of family members and only $20.1 \%$ admitted that they had exposure to care for dying person.
Table 1 summarizes the response that reflects the knowledge of the students on palliative care. We took percentage of more than $80 \%$ to be considered as satisfactory response to the questions. Most of the students (those who answered $>80 \%$ ) understood that palliative care improved quality of life, relieving suffering, did not hastening death and covered thorough assessment of physical, psychosocial, emotional and spiritual. There were $22.3 \%$ who believed that palliative care aimed to prolong life and a good $59 \%$ of the students thought palliative care affirmed life. Similarly $59 \%$ also believed that physicians should address psychosocial issues and 36\% agreed on resuscitation on advanced cancer. A vast $66.9 \%$ of respondents believed that palliative care is required for end stage organ failure. On the thoughts that communication of prognosis should be done with the family members only, a mere $26 \%$ believed in it.

Attitudes of respondents toward palliative care are summarised in Table 2. About nearly a third $(30.2 \%)$ of the respondents disagreed on the statement that the medical personnel find more satisfaction when working with dying patients. Large number of the respondents agreed (86.3\%) patients should know their diagnosis even death is imminent, as well as $64.7 \%$ of them disagreed that terminally ill patients required less medical assessment. As many as $49.7 \%$ of the respondents believed that nurses should be the professional who would be dealing with the emotional reaction of terminal patients. A higher $69.8 \%$ believed that the patients were giving up because the medical personnel themselves were giving up on the patients. The thought that morphine addiction would be a problem for terminally patients who was commenced on morphine was recorded as $46.1 \%$.

Table 3 shows how far the current medical curriculum prepared the students in providing the care to the end of life patients. The table shows that the respondents are well equipped to help the family members during bereavement period. 
Table 1: Percentages of correct responses to knowledge domain among respondents

\begin{tabular}{|c|c|c|c|}
\hline \multicolumn{2}{|l|}{ 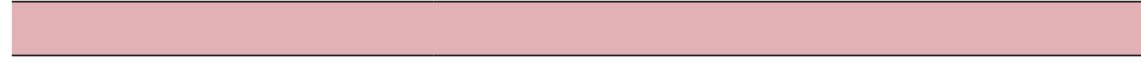 } & Yes & No \\
\hline \multicolumn{4}{|l|}{ Palliative care is about: } \\
\hline \multicolumn{2}{|l|}{ Improving quality of life } & $94.2 \%$ & $5.8 \%$ \\
\hline \multicolumn{2}{|l|}{ Relieving suffering } & $96.4 \%$ & $3.6 \%$ \\
\hline \multicolumn{2}{|l|}{ Hastening death } & $15.8 \%$ & $84.2 \%$ \\
\hline \multicolumn{2}{|c|}{ Prolonging life } & $22.3 \%$ & $77.7 \%$ \\
\hline \multicolumn{2}{|c|}{ Applicable for terminal stage } & $92.1 \%$ & $7.9 \%$ \\
\hline \multicolumn{2}{|c|}{ Thorough assessment of physical, emotional, psychosocial and spiritual } & $97.8 \%$ & $2.2 \%$ \\
\hline \multicolumn{2}{|c|}{ Affirms life } & $59.0 \%$ & $41.0 \%$ \\
\hline \multicolumn{2}{|c|}{ Pain management is the most important component of palliative care } & $89.2 \%$ & $10.8 \%$ \\
\hline \multicolumn{2}{|c|}{ Multidisciplinary team is important in the management of palliative patients } & $92.1 \%$ & $7.9 \%$ \\
\hline \multicolumn{2}{|c|}{ There are many ethical dilemmas in caring for dying patients } & $97.8 \%$ & $2.2 \%$ \\
\hline \multicolumn{2}{|c|}{ It's the role of physicians to address the psychosocial issues of dying patient } & $59.0 \%$ & $41.0 \%$ \\
\hline \multicolumn{2}{|c|}{ Resuscitation is appropriate in advanced cancer } & $36.0 \%$ & $64 \%$ \\
\hline \multicolumn{2}{|c|}{ Outcome of resuscitation in advanced metastatic cancer are good } & $7.9 \%$ & $92.1 \%$ \\
\hline \multicolumn{2}{|c|}{$\begin{array}{l}\text { Patients and relatives should be involved in decision making of "not for } \\
\text { resuscitation" }\end{array}$} & $92.8 \%$ & $7.2 \%$ \\
\hline \multirow{3}{*}{ Palliative care is needed: } & For all dying patients & $84.2 \%$ & $15.8 \%$ \\
\hline & For metastatic cancer with uncontrolled pain & $95.7 \%$ & $4.3 \%$ \\
\hline & For end stage renal/heart failure & $66.9 \%$ & $33.1 \%$ \\
\hline \multirow{3}{*}{ Morphine: } & Causes death in all dying patients & $6.5 \%$ & $93.5 \%$ \\
\hline & Improves the quality of life & $82.0 \%$ & $18.0 \%$ \\
\hline & Relieves all kind of pain & $60.4 \%$ & $39.6 \%$ \\
\hline \multirow{3}{*}{$\begin{array}{l}\text { Common side effect of } \\
\text { morphine is: }\end{array}$} & Nausea and vomiting & $90.7 \%$ & $9.3 \%$ \\
\hline & Constipation & $60.9 \%$ & $39.1 \%$ \\
\hline & Addiction & $87.8 \%$ & $12.2 \%$ \\
\hline \multirow{3}{*}{$\begin{array}{l}\text { Component of a good } \\
\text { death is: }\end{array}$} & Pain and symptom management & $97.1 \%$ & $2.9 \%$ \\
\hline & Clear decision making & $92.8 \%$ & $7.2 \%$ \\
\hline & Preparation for death & $97.8 \%$ & $2.2 \%$ \\
\hline \multirow{4}{*}{$\begin{array}{l}\text { When communicating } \\
\text { prognosis, }\end{array}$} & It should clearly communicated & $99.3 \%$ & $0.7 \%$ \\
\hline & Only to family members & $26.6 \%$ & $73.4 \%$ \\
\hline & Not communicating lead to lack of trust & $88.5 \%$ & $11.5 \%$ \\
\hline & $\begin{array}{l}\text { Patients choices should be clearly } \\
\text { communicated }\end{array}$ & $97.1 \%$ & $2.9 \%$ \\
\hline
\end{tabular}


Table 2: Response frequencies for 20 attitudes toward palliative terminal cancer care among the fifth year USM medical students

\begin{tabular}{|c|c|c|c|c|c|}
\hline & $\begin{array}{l}\text { Strongly } \\
\text { agree }\end{array}$ & Agree & Uncertain & Disagree & $\begin{array}{l}\text { Strongly } \\
\text { disagree }\end{array}$ \\
\hline $\begin{array}{l}\text { Medical personnel find it more } \\
\text { satisfaction to work with patients who } \\
\text { are expected to improve than who are } \\
\text { likely to die. }\end{array}$ & $18.0 \%$ & $28.1 \%$ & $13.7 \%$ & $23.0 \%$ & $7.2 \%$ \\
\hline $\begin{array}{l}\text { The patient is better off knowing her/his } \\
\text { diagnosis even it carries an implication } \\
\text { of imminent death. }\end{array}$ & $45.3 \%$ & $41.0 \%$ & $10.1 \%$ & $2.9 \%$ & $0.7 \%$ \\
\hline $\begin{array}{l}\text { If the patient talk about fear of death, } \\
\text { doctors and nurses should reassure him/ } \\
\text { her that there is little to worry about. }\end{array}$ & $7.9 \%$ & $29.5 \%$ & $28.8 \%$ & $23.0 \%$ & $10.8 \%$ \\
\hline $\begin{array}{l}\text { Medical personnel find it more } \\
\text { satisfaction to work with patients who } \\
\text { are expected to improve than who are } \\
\text { likely to die. }\end{array}$ & $18.0 \%$ & $28.1 \%$ & $13.7 \%$ & $23.0 \%$ & $7.2 \%$ \\
\hline $\begin{array}{l}\text { The patient is better off knowing her/his } \\
\text { diagnosis even it carries an implication } \\
\text { of imminent death. }\end{array}$ & $45.3 \%$ & $41.0 \%$ & $10.1 \%$ & $2.9 \%$ & $0.7 \%$ \\
\hline $\begin{array}{l}\text { If the patient talk about fear of death, } \\
\text { doctors and nurses should reassure him/ } \\
\text { her that there is little to worry about. }\end{array}$ & $7.9 \%$ & $29.5 \%$ & $28.8 \%$ & $23.0 \%$ & $10.8 \%$ \\
\hline $\begin{array}{l}\text { Terminal stage cancer patients need } \\
\text { less frequent medical assessment than } \\
\text { patients with active, rapid changed } \\
\text { disease. }\end{array}$ & $3.6 \%$ & $15.8 \%$ & $15.8 \%$ & $46.0 \%$ & $18.7 \%$ \\
\hline $\begin{array}{l}\text { Even if they don't ask, relatives should } \\
\text { be advised when death is imminent in } \\
\text { terminally ill patients. }\end{array}$ & $41.7 \%$ & $52.5 \%$ & $4.3 \%$ & $0 \%$ & $1.4 \%$ \\
\hline $\begin{array}{l}\text { Dealing with terminal cancer patient } \\
\text { makes one aware of one's own feeling } \\
\text { regarding terminally ill. }\end{array}$ & $45.3 \%$ & $48.9 \%$ & $3.6 \%$ & $0 \%$ & $1.4 \%$ \\
\hline $\begin{array}{l}\text { Family members who stay close to a } \\
\text { terminal cancer patient often interfere } \\
\text { with professional's work with the patient. }\end{array}$ & $10.8 \%$ & $23.7 \%$ & $25.9 \%$ & $31.7 \%$ & $7.9 \%$ \\
\hline $\begin{array}{l}\text { If given a choice, I prefer avoid contact } \\
\text { with or care for terminal cancer patient. }\end{array}$ & $6.5 \%$ & $8.6 \%$ & $19.4 \%$ & $41.7 \%$ & $23.0 \%$ \\
\hline $\begin{array}{l}\text { Nurses should be the primary } \\
\text { professionals equipped to deal with the } \\
\text { reaction of terminal cancer patient. }\end{array}$ & $14.4 \%$ & $35.3 \%$ & $13.7 \%$ & $30.9 \%$ & $5.8 \%$ \\
\hline $\begin{array}{l}\text { It is important for the physicians to help } \\
\text { patients prepare for terminal stage of } \\
\text { cancer. }\end{array}$ & $45.3 \%$ & $51.1 \%$ & $2.2 \%$ & $0 \%$ & $1.4 \%$ \\
\hline $\begin{array}{l}\text { Terminal cancer patient should be } \\
\text { allowed to gradually degradation } \\
\text { without efforts to prolong their well- } \\
\text { being. }\end{array}$ & $7.9 \%$ & $15.8 \%$ & $27.3 \%$ & $33.1 \%$ & $15.8 \%$ \\
\hline
\end{tabular}


Table 2: (continued)

\begin{tabular}{|c|c|c|c|c|c|}
\hline & $\begin{array}{l}\text { Strongly } \\
\text { agree }\end{array}$ & Agree & Uncertain & Disagree & $\begin{array}{l}\text { Strongly } \\
\text { disagree }\end{array}$ \\
\hline $\begin{array}{l}\text { Physicians play a key role in reducing } \\
\text { the suffering of the patients with } \\
\text { hopeless of advanced cancer. }\end{array}$ & $43.2 \%$ & $51.8 \%$ & $2.9 \%$ & $0 \%$ & $2.2 \%$ \\
\hline $\begin{array}{l}\text { Sometimes terminal cancer patients } \\
\text { give up on themselves because the } \\
\text { medical personnel have given up on } \\
\text { them. }\end{array}$ & $19.4 \%$ & $50.4 \%$ & $19.4 \%$ & $8.6 \%$ & $2.2 \%$ \\
\hline $\begin{array}{l}\text { I usually feel at ease talking with other } \\
\text { physicians about terminal cancer } \\
\text { patients for whom we shared personal } \\
\text { responsibility. }\end{array}$ & $16.5 \%$ & $43.9 \%$ & $30.9 \%$ & $7.2 \%$ & $1.4 \%$ \\
\hline $\begin{array}{l}\text { I would not be concerned about } \\
\text { addiction if a family member of my } \\
\text { family was given morphine for cancer } \\
\text { pain. }\end{array}$ & $7.9 \%$ & $22.3 \%$ & $23.7 \%$ & $36.0 \%$ & $10.1 \%$ \\
\hline $\begin{array}{l}\text { It is appropriate for cancer patients to } \\
\text { receive opioid analgesic at any time in } \\
\text { their disease course. }\end{array}$ & $10.8 \%$ & $38.1 \%$ & $31.7 \%$ & $14.4 \%$ & $5.0 \%$ \\
\hline $\begin{array}{l}\text { The terminal cancer patients who } \\
\text { mostly talk about their future plan for } \\
\text { work, family, trips etc. do not realise the } \\
\text { seriousness of his/her condition. }\end{array}$ & $4.3 \%$ & $13.7 \%$ & $22.3 \%$ & $42.4 \%$ & $17.3 \%$ \\
\hline $\begin{array}{l}\text { The terminal cancer patients mostly } \\
\text { mourn their own coming death. }\end{array}$ & $7.2 \%$ & $33.1 \%$ & $29.5 \%$ & $25.9 \%$ & $4.3 \%$ \\
\hline $\begin{array}{l}\text { Doctors and nurses should be detached } \\
\text { emotionally if they are to work in their } \\
\text { best interest of terminal cancer patient. }\end{array}$ & $13.7 \%$ & $21.6 \%$ & $13.7 \%$ & $34.5 \%$ & $16.5 \%$ \\
\hline $\begin{array}{l}\text { Physicians should try to explain to a } \\
\text { patient that they should not be angry if } \\
\text { events are out of their control. }\end{array}$ & $18.7 \%$ & $50.4 \%$ & $15.8 \%$ & $9.4 \%$ & $5.8 \%$ \\
\hline
\end{tabular}

There was a close $62.6 \%$ who felt that they were able to treat neuropathic and somatic pain, as with $56.8 \%$ who were able to determine the needs of the patients and referral to the hospice or palliative care team. As to whether that the current curriculum had explicitly taught them on assessment and management of depression at the end of life situation, $43.9 \%$ of the respondents were agreeable to it. Less than $50 \%$ of the respondents are confident to discuss on withdrawal of care, inform that the patient is dying and teaching family members of home care.
In Table 4 depicts of the answer from students related to perceived barriers in palliative care. We took percentage $>70 \%$ as strongly associated factors. We found knowledge, learning and practice deficiency, uncertainty of timing, lack of services, diversity in cultural, custom, ethnic and religiosity, experience, communication issues, difficult decision making, ethical dilemma and attitudes towards death, have remained important barriers to be resolved.

Table 5 illustrates the self-assessment of individual students towards palliative care. 
Table 3: Response frequencies towards current medical curricula prepared the medical students to provide and teach end of life

Sometimes students learn from being explicitly taught and sometimes by learning skills on their own. I'd like to ask about what you have been explicitly taught in the medical school courses and clerkship, including what you have been taught in one to one sessions with the senior doctors. How well has the medical education prepared you to:

\begin{tabular}{|c|c|c|c|}
\hline Preparation to provide care & Very well & Moderately & Not well \\
\hline Talk to a patient about his or her thoughts and fears of dying & $12.2 \%$ & $48.9 \%$ & $38.8 \%$ \\
\hline Address cultural issues related to a patient's end of life & $12.2 \%$ & $48.2 \%$ & $39.6 \%$ \\
\hline Address spiritual issues related to a patient's end of life & $18.0 \%$ & $46.8 \%$ & $35.2 \%$ \\
\hline Manage your own feeling about a patient's dying and death & $19.4 \%$ & $54.7 \%$ & $25.9 \%$ \\
\hline Help family members during the bereavement & $42.4 \%$ & $47.5 \%$ & $10.1 \%$ \\
\hline Manage pain of a dying patient & $21.6 \%$ & $43.9 \%$ & $34.5 \%$ \\
\hline Discuss end of life decisions & $15.1 \%$ & $33.8 \%$ & $51.1 \%$ \\
\hline Preparation to teach & & & \\
\hline Talk to a patient about his or her thoughts and fears of dying & $15.8 \%$ & $44.6 \%$ & $39.6 \%$ \\
\hline Address cultural issues related to a patient's end of life & $10.8 \%$ & $48.9 \%$ & $40.3 \%$ \\
\hline Address spiritual issues related to a patient's end of life & $15.8 \%$ & $46.0 \%$ & $38.1 \%$ \\
\hline Manage your own feeling about a patient's dying and death & $18.0 \%$ & $51.1 \%$ & $30.9 \%$ \\
\hline Help family members during the bereavement & $12.2 \%$ & $43.2 \%$ & $44.2 \%$ \\
\hline Manage pain of a dying patient & $13.7 \%$ & $48.9 \%$ & $37.0 \%$ \\
\hline Discuss end of life decisions & $12.9 \%$ & $37.4 \%$ & $49.6 \%$ \\
\hline Specific end of life topics covered or taught & $12.2 \%$ & $40.3 \%$ & $45.3 \%$ \\
\hline $\begin{array}{l}\text { Thinking again only about the coursework and clerkship, } \\
\text { have you been explicitly taught how to: }\end{array}$ & Yes & No & \\
\hline Treat neuropathic versus somatic pain & $62.6 \%$ & $37.4 \%$ & \\
\hline Determine when to refer patients to hospice/palliative care & $56.8 \%$ & $43.2 \%$ & \\
\hline Recognise tolerance to opioids & $55.4 \%$ & $44.6 \%$ & \\
\hline Assess and manage depression at the end of life & $43.9 \%$ & $56.1 \%$ & \\
\hline Discuss treatment withdrawal with patients and family & $49.6 \%$ & $50.4 \%$ & \\
\hline Tell the patients that he or she is dying & $48.9 \%$ & $51.1 \%$ & \\
\hline Teach family to provide homecare for dying patient & $47.5 \%$ & $52.5 \%$ & \\
\hline
\end{tabular}

As many as $65.5 \%$ of the students admitted that they were not confident in assessing and examining the patients with cancer pain. Similarly, a slightly higher $62.6 \%$ felt that they still lacked in the basic principles of palliative care. When being asked about the level of confidence to integrate the psychological aspect in managing terminally ill patients, more than half of the respondents are not confident to do that $(59 \%)$, as well as for spiritual care. Nearly one third of the respondents $(34.6 \%)$ felt confident to practice palliative care to their patients. Retrospectively, more than half of the final year students felt that they were lacking in communication skills with the 
Table 4: Response frequencies regarding barriers in palliative care

\begin{tabular}{lccc}
\hline & Yes & Neutral & No \\
\hline Knowledge, learning and practice deficient & $82.7 \%$ & $10.1 \%$ & $6.5 \%^{*}$ \\
Exposure to clinical practice & $85.6 \%$ & $10.8 \%$ & $3.6 \%$ \\
Unsure the timing for palliative care & $71.2 \%$ & $22.3 \%$ & $6.5 \%$ \\
Conflict among healthcare professional & $65.5 \%$ & $24.5 \%$ & $10.1 \%$ \\
Lack of services & $78.4 \%$ & $15.1 \%$ & $6.5 \%$ \\
Lack multidisciplinary team & $69.1 \%$ & $22.3 \%$ & $8.6 \%$ \\
Cultural, custom, ethnic and religious differences & $78.4 \%$ & $17.3 \%$ & $3.6 \%{ }^{*}$ \\
Communication issues & $84.9 \%$ & $7.9 \%$ & $7.2 \%$ \\
Access to information & $68.3 \%$ & $16.5 \%$ & $15.1 \%$ \\
Decision making & $74.1 \%$ & $20.9 \%$ & $4.3 \%{ }^{*}$ \\
Not holistic approach & $63.3 \%$ & $25.9 \%$ & $10.8 \%$ \\
Ethical dilemma & $80.6 \%$ & $13.7 \%$ & $5.8 \%$ \\
Availability of medication and support & $68.3 \%$ & $23.7 \%$ & $7.9 \%$ \\
Attitudes toward death & $78.4 \%$ & $17.3 \%$ & $4.3 \%$ \\
\hline
\end{tabular}

Table 5: Self-assessment towards palliative care among respondents

\begin{tabular}{lcccc}
\hline & Confident & $\begin{array}{c}\text { Rather } \\
\text { confident }\end{array}$ & $\begin{array}{c}\text { Rather non } \\
\text { confident }\end{array}$ & $\begin{array}{c}\text { Non } \\
\text { confident }\end{array}$ \\
\hline $\begin{array}{l}\text { Regarding assessment and examination of } \\
\text { patients with cancer pain I feel... }\end{array}$ & $5.8 \%$ & $28.8 \%$ & $54.0 \%$ & $11.5 \%$ \\
$\begin{array}{l}\text { Regarding the basic principles and contents } \\
\text { of palliative care I feel... }\end{array}$ & $5.8 \%$ & $31.7 \%$ & $54.7 \%$ & $7.9 \%$ \\
$\begin{array}{l}\text { Regarding the integration of psychological } \\
\text { aspects in the treatment and }\end{array}$ & $10.1 \%$ & $30.9 \%$ & $43.9 \%$ & $15.1 \%$ \\
$\begin{array}{l}\text { accompaniment of severely ill and dying } \\
\text { patients I feel... }\end{array}$ & & & & \\
$\begin{array}{l}\text { Regarding the medical treatment of cancer } \\
\text { pain I feel... }\end{array}$ & $5.0 \%$ & $46.0 \%$ & $41.0 \%$ & $7.9 \%$ \\
$\begin{array}{l}\text { Regarding the integration of spiritual } \\
\text { aspects in the treatment and } \\
\text { accompaniment of severely ill and dying } \\
\text { patients I feel... }\end{array}$ & $7.9 \%$ & $41.7 \%$ & 36.0 & $13.7 \%$ \\
$\begin{array}{l}\text { Regarding the treatment of symptoms, } \\
\text { which might occur in advanced cancer, I } \\
\text { feel... }\end{array}$ & $4.3 \%$ & $50.4 \%$ & $37.4 \%$ & $7.9 \%$ \\
$\begin{array}{l}\text { Regarding communicating with severely ill } \\
\text { and dying patients I feel... }\end{array}$ & $5.8 \%$ & $33.8 \%$ & $51.1 \%$ & $9.4 \%$ \\
$\begin{array}{l}\text { In explaining to a patient the inability to } \\
\text { cure her/his disease, I feel... }\end{array}$ & $3.6 \%$ & $25.2 \%$ & $54.0 \%$ & $17.3 \%$ \\
$\begin{array}{l}\text { In explaining to a patient the change } \\
\text { from a tumor specific treatment (e.g. } \\
\text { chemotherapy) to palliative care I feel... }\end{array}$ & $4.3 \%$ & $29.5 \%$ & $53.2 \%$ & $12.9 \%$ \\
$\begin{array}{l}\text { Regarding the treatment of and } \\
\text { accompaniment of terminally ill and dying } \\
\text { patients I feel... }\end{array}$ & $1.4 \%$ & $40.3 \%$ & $46.8 \%$ & $11.5 \%$ \\
\hline
\end{tabular}


dying patient $(60.5 \%)$, explaining inability to cure the disease $(71.3 \%)$, and giving treatment and accompaniment of terminally ill patients (58.3\%).

\section{Discussion}

Across the globe, death is still viewed as medical failure and emphasis on the importance of palliative care and end of life issues is minimal in the undergraduate medical curriculum. This resulted in unprepared doctors when encountering patients who are dying or at the end of their lives. Palliative care is often perceived as peripheral subject to mainstream medicine. The current USM medical curricula have inadequate inclusion of palliative care content, skills and exposure. Teaching in end-of-life mainly stressed theoretical aspects as per textbooks only (1). The study used existing tools to understand the level of knowledge and attitude of medical students towards the practice of palliative care. This is vital for developing a better coverage of palliative care in our future medical curricula. Adequate learning of palliative care prior to graduating as full medical practitioners is vital to ensure maximum competency.

We conducted the study at the beginning of the final clinical year. This gives some reflective moments related to their palliative care experiences and knowledge. Most of the students could give an accurate definition of palliative care, but there was patchy understanding of this term. Palliative care is about affirming life, and has to be started at the early stage of the diagnosis. The study documented only 59\% agreed on the statement about affirming life and $22.3 \%$ believed that palliative care can prolonged life. There is a contrast finding whereby majority of the students $(92.1 \%)$ strongly felt that palliative care is attributed to terminal care. Palliative care should be geared towards many life limiting and life threatening conditions but should be commenced early. Only $66.9 \%$ believed that patients with end organ failure should get palliative care. There were several key area, despite strong understanding to palliative care knowledge, many of the students have had a wrong idea on when and who palliative care should be initiated.

More than half of the students denied about their exposure to the palliative care throughout their studies in USM. Palliative care has become a national policy in Malaysia since 2000 (15). At USM the exposure is mainly through indirect medical contact. Structured palliative care teaching module is unavailable at this stage. Main bulk of contact with patients who required palliative care were through medical and paediatric postings. Unfortunately, this is not a guided teaching but rather than using "Problem Solving Learning" methodology as a continuation of USM learning philosophy. The study showed students' knowledge and experiences are mixed with correct and incorrect information. Exposure to palliative care needs to be stepped up to meet the expected undergraduate standard. This is supported in the literature. Until now, palliative care training has not been fully included in medical education (14). Hammel et al. (16) found in their comparative study that $85 \%$ of the students in British medical schools and $25 \%$ of those in the United States who underwent clinical rotation on end of life care. Interesting facts as well that $50.4 \%$ of the respondents in our study admitted of not having palliative care exposure despite available session throughout the years. In our study also, more than half of the students admitted about their uncertainty when discussing end of life decision. About one third of them also felt uncomfortable addressing cultural and spiritual issues related to the end of life. This is an understandable concern for students due to lack of experience and clinical exposure to discuss in the matter.

Regarding the attitudes of our students toward palliative care, most viewed palliative care positively and were not influenced by their cultural and religious affiliation. There was a strong consensus of $86.3 \%$ amongst the students in agreement about 
communicating the diagnosis to the patients. This is almost similar findings by Wang et al. (17). Most of the students also believed that the physicians play a key role in reducing patients' suffering. However, contrasting findings are seen in our study compared to studies conducted in Japan, Greece and Ethiopia, whereby practitioners believed that by telling truth about their diagnosis may lead to hastening of their death (4). Cultural context, religious affair, local customary practice and population or racial belief influenced the decision making process and understanding surrounding death and dying process. About half of the students felt that patients should not be allowed to prolong life unnecessarily. This includes the concept of "Do Not Resuscitation" (DNR) in Malaysian setting. Although advanced care planning is not well developed locally and discussing on end of life with elderly is considered a taboo and sensitive issue, the students seem to aware that DNR order and end of life discussion is essential piece of information.

Psychosocial and emotional aspects have been highlighted as concern among the participating respondents. Their attitude varied in the matter related to psychological suffering. There are dynamic of care when dealing with terminally ill patient. Some have positive reactions which may be due to their understanding of the concept of palliative care but some students had negative attitudes due to suboptimal understanding of psychological and emotional support. The opinion that opioid is an appropriate drug of choice for the cancer patients, $48.1 \%$ of them agreed to it. The low response perhaps reflects misunderstanding of opioid addiction and fear of morphine abuse especially in the community. This negativity was similar to Weinstein et al. (18). One main reason related to this is due to negative attitude in opioid use especially at terminal stage. We felt that students' understanding was insufficient and inadequate.

Overall, the result of the study indicated poor preparedness among the medical students at USM. This result may be due to the factors such as knowledge deficiency, poor preparation, lack of exposure, under stimulated learning and practice that act as barrier towards successful palliative care. Improving medical curricula in palliative and end of life care requires combination efforts from all; school, lecturers and also students. It requires implementation of structured and systematic emphasis on the knowledge and practice. This would include a more equitable learning environment for the students during clerkship and clinical training.

\section{Conclusion}

Widening gaps are a recognised feature in undergraduate palliative care education. The structured learning has little emphasis of this subject thus lead to unpreparedness students when entering the intern world. Remedial actions should be taken to improve learning outcome and understanding via practical experience and discussion, and structured medical curriculum. Gradual exposure of palliative care patients may be the way forward for students to learn not only medical subject but also community ethics, behaviour and humanities. 


\section{References}

1. Sadhu S, Salins NS, Kamath A. Palliative care awareness among Indian undergraduate health care students: a needs-assessment study to determine incorporation of palliative care education in undergraduate medical, nursing and allied health education. Indian Journal of Palliative Care. 2010;16:154-9.

2. Eyigor S. Fifth-year medical students' knowledge of palliative care and their view on the subject. Journal of Palliative Medicine. 2013;16:941-6. doi: 10.1089/ jpm.2012.0627.

3. Battersby C. What shall we teach our students about breast cancer? A personal review. Aust N Z J Surg. 1977;47:810-15. doi: 10.1111/j.1445-2197.1977.tb06633.x.

4. Budkaew J, Chumworathayi B. Knowledge and attitudes toward palliative terminal cancer care among Thai generalists. Asian Pac J Cancer Prev. 2013;14:6173-80. doi:10.7314/APJCP.2013.14.10.6173.

5. Bui EC, Higgins MA. The knowledge, attitudes and practices of physicians in the end-of-life care. University of Toronto Medical Journal. 2001;79:88-93.

6. Siu MW, Cheung TY, Chiu MM, Kwok TY, Choi WL, Lo TK, Ting WM, Yu PH, Cheung CY, Wong JG, Chua SE. The preparedness of Hong Kong medical students towards advance directives and end-of-life issues. East Asian Arch Psychiatry. 2010;20:155-62.

7. Pinhiero A, Nakazone MA, Leal FS, Pinhell MAS, Souza DRS, Cipullo JP. Medical students' knowledge about end-of-life decision making. Revista Braseleira De Educaco Medica. 2011;35: 171-76.

8. Sullivan AM, Lakoma MD, Block SD. The status of medical education in the end-oflife: a national report 2003. J Gen Intern Med. 2003;18(9):685-95.
9. Biswal BM, Zakaria A, Baba AA, Ja'afar R. Assessment of knowledge, attitude and exposure to oncology and palliative care in undergraduate medical students. Med J Malaysia. 2004;59:78-83.

10. Shaikh AJ, Khokar NA, Raza S, Kumar S, Haider G, Haider AG, Muhammad R, Masood N. Knowledge, attitude and practices of non-oncologist physicians regarding cancer and palliative care: a multicenter study. Asian Pac J Cancer Prev. 2008; 9(4):581-84.

11. Pinheira TAP, de Benedetto MAC, Levites MR, del Giglio A, Blasco PG. Teaching palliative care to residents and medical students. Fam Medicine. 2010:42;580-82.

12. Lloyd-Williams M, Dogra N. Attitudes of preclinical medical students towards caring for chronically ill and dying patients: does palliative care teaching make a difference? Postgrad Med J. 2004;80:31-4. doi: 10.1136/pmj.2003.009571.

13. Chong LA, Khalid F. Paediatric palliative care in Malaysia: survey of knowledge base and barriers to referral. 2014;22:195-200.

14. Weber M, Schmiedel S, Nauck F, AltEpping B. Knowledge and attitude of final-year medical students in Germany towards palliative care: an interinstitutional questionnaire based study. BMC Palliat Care. 2011;10:19. doi: 10.1186/1472-684X10-19.

15. National Policy for Palliative Care in Malaysia. 2000. Medical Services Unit, Medical Services Development Section of the Medical Development Division, Ministry of Health Malaysia. Palliative care services operational policy. 1st ed. Malaysia: National Library of Malaysia; 2000.

16. Hammel JF, Sullivan AM, Block SD, Twycross R. End-of-life and palliative care education for final year medical students: a comparison of Britain and United States. J Palliat Med. 2007;10:1356-66. doi: 10.1089/ jpm.2007.0059. 
17. Wang XS, Di LJ, Reyes-Gibby CC, Guo H, Liu SJ, Cleeland CS. End of life in urban area of China: a survey of 60 oncology clinicians. J Pain and Sympton Manage. 2004;27(2):125-32. doi: 10.1016/j. jpainsymman.2003.06.002.
18. Weinstein SM, Laux LF, Lorimor RJ, Thorpe DM, Merrill JM. Medical students' attitudes toward pain and the use of opioid analgesics: implications for changing medical school curriculum. South Med J. 2000;93(5):472-78. 